\title{
Results of the Characterization and Dissolution Tests of Samples from Tank $16 \mathrm{H}$
}

by

M. S. Hay

RECORDS ADMINISTRATION

Westinghouse Savannah River Company

Savannah River Site

Aiken, South Carolina 29808

This paper was prepared in connection with work done under the above contract number with the U.S. Department of Energy. By acceptance of this paper, the publisher and/or recipient acknowledges the U. S. Government's right to retain a nonexclusive, royalty-free license in and to any copyright covering this paper, along with the right to reproduce and to authorize others to reproduce all or part of the copyrighted paper. 


\section{DISCLAIMER}

This report was prepared as an account of work sponsored by an agency of the United States Government. Neither the United States Government nor any agency thereof, nor any of their employees, makes any warranty, express or implied, or assumes any legal liability or responsibility for the accuracy, completeness, or usefulness of any information, apparatus, product, or process disclosed, or represents that its use would not infringe privately owned rights. Reference herein to any specific commercial product, process, or service by trade name, trademark, manufacturer, or otherwise does not necessarily constitute or imply its endorsement, recommendation, or favoring by the United States Government or any agency thereof. The views and opinions of authors expressed herein do not necessarily state or reflect those of the United States Government or any agency thereof.

This report has been reproduced directly from the best available copy.

Available to DOE and DOE contractors from the Office of Scientific and Technical Information, P.O. Box 62, Oak Ridge, TN 37831; prices available from (615) 576-8401.

Available to the public from the National Technical Information Service, U.S. Department of Commerce, 5285 Port Royal Road, Springfield, VA 22161. 
Results of the Characterization and Dissolution Tests of Samples from Tank 16H

M. S. Hay

Publication Date: January 18, 1999

Westinghouse

Savannah River Company

Aiken, SC 29808 


\title{
Results of the Characterization and Dissolution Tests of Samples from Tank 16H
}

\author{
M. S. Hay \\ Waste Processing Technology Section \\ Savannah River Technology Center \\ Westinghouse Savannah River Co.
}

\section{Summary}

Samples from Tank $16 \mathrm{H}$ annulus and one sample from the tank interior were characterized to provide a source term for use in fate and transport modeling. Four of the annulus samples appeared to be similar based on visual examination and were combined to form a composite (CPHTF-088). One of the annulus samples (HTF-087) appeared to be different from the other four based on visual examination and was analyzed separately.

The analytical results of the tank interior sample indicate the sample is composed of predominantly iron containing compounds. Low concentrations of $\mathrm{Cs}^{137}, \mathrm{Sr}^{90}$, and $\mathrm{Tc}^{99}$ were also measured.

Both of the annulus samples are composed mainly of sodium salts, however, the composite sample contained significantly more sludge/sand material of low solubility. The $\mathrm{Cs}^{137}$ concentration in the composite sample was $50 \mathrm{X}$ higher than the tank interior sample and $25 \mathrm{X}$ higher than the other annulus sample (HTF-087). The $\mathrm{Tc}^{99}$ concentration in the composite sample and the single annulus sample were found to be of the same order of magnitude.

The characterization of the Tank $16 \mathrm{H}$ annulus and tank interior samples was hampered by the high dose rate and the nature of the samples. The difficulties resulted in large uncertainties in the analytical data. The large uncertainties coupled with the number of important species below detection limits indicate the need for reanalysis of the Tank $16 \mathrm{H}$ samples as funding becomes available. Recommendations on potential remedies for these difficulties are provided.

Dissolution tests were conducted on the two annulus samples (HTF-087 and CPHTF-088) to explore the ability of tank farm compatible reagents to dissolve the material. For each annulus sample, duplicate tests with four reagents $(3 \mathrm{M} \mathrm{NaOH}, 0.01 \mathrm{M} \mathrm{NaOH}$, Process Water, and $4 \mathrm{wt} \%$ Oxalic Acid) were conducted at ambient temperature. In addition, dissolution tests at $60^{\circ} \mathrm{C}$ were conducted on the composite sample.

In general, none of the reagents appeared to be effective in dissolving the composite sample even after two contacts at elevated temperature. In contrast to the composite sample, all of the reagents dissolved a large percentage of the HTF- 087 solids after two contacts at ambient temperature. 


\section{Introduction}

In support of the closure of Tank $16 \mathrm{H}$, a sample of the solid residue on the bottom of the tank interior and five samples from the tank annulus were sent to SRTC for analysis. The radiochemical composition of the samples from the tank interior and the annulus defines the source term for use in fate and transport modeling. In addition, the samples from the tank annulus were used for dissolution tests to evaluate the effectiveness of various cleaning alternatives. The results of the characterization and dissolution tests are reported.

A previously issued characterization plan and task plan outlined the scope, general procedures, and analyses required to define the source term and the effectiveness of the dissolution tests. ${ }^{1,2}$ High-Level Waste Engineering requested this work under a Technical Task Request. ${ }^{3}$

\section{Sample Description}

The six samples from Tank $16 \mathrm{H}$ were composed of one sample (HTF-086) from the tank interior and 5 samples from the tank annulus (HTF-087 to 091). Three types of sampling devices were employed to obtain the samples from Tank $16 \mathrm{H}$. All three sampling devices consisted of a metal cylinder with screen, flap, or hinged disk at the bottom to trap solids. The opening of the samples in the SRTC Shielded Cells was videotaped using an in-cell fiber-optic video camera. Still images captured from the video tape for each sample are shown in Figure 1.

The sample from the interior Tank $16 \mathrm{H}(\mathrm{HTF}-086)$ contained only a small amount of brown solids. The supernate drained from the sampler during removal from the tank. The radiation rate measured on this sample was low ( $<500 \mathrm{mRad} / \mathrm{hr})$.

The annulus sample HTF-087 was composed of crystalline white solids containing a small amount of dark colored particles throughout the sample. The remaining four annulus samples (HTF-088 to -091) contained a gray crystalline material with a greater amount of dark colored particles throughout the sample. Based on visual observations, four of the annulus samples (HTF-088 to -091) appeared to contain similar material and were combined to make a composite sample (CPHTF-088). The radiation rates measured on several of the annulus samples were high (>10 Rad/hr).

\section{Experimental}

Sample Preparation for Characterization

A portion of each sample (HTF-086, HTF-087, and the composite sample CPHTF-088) was placed into a separate Teflon beaker and dried at $100^{\circ} \mathrm{C}$ until at constant weight. For each sample, portions of the dried solids were dissolved in triplicate by contacting with aquaregia. Due to the high dose rate of the annulus samples, each of the three aqua-regia 
digestions for samples HTF-087 and CPHTF-088 were further treated by two different methods. A portion of each aqua-regia digestion was diluted by a factor of 50 to $100 \mathrm{X}$ and removed from the Shielded Cells. Another portion of each digestion was treated with AMP-1 resin to remove $\mathrm{Cs}^{137}$. The aliquot treated with the resin was removed from the Shielded Cells without further dilution. The method employing the cesium removal resin was conducted due to concerns that large dilutions would not allow determination of critical species present in low concentrations in the samples.

A portion of the composite sample (CPHTF-088) was used to prepare triplicate samples for the determination of the soluble solids composition. The samples were prepared by contacting $\sim 0.1 \mathrm{~g}$ of the composite sample with $100 \mathrm{~mL}$ of inhibited water $(0.01 \mathrm{M} \mathrm{NaOH})$. These samples were removed from the Shielded Cells and sent to ADS without further dilution.

\section{Analytical Methods}

The following analytical methods were used by ADS for determination of specific species. Nitrate, nitrite, sulfate, chloride, fluoride, oxalate and phosphate were measured by ion chromatography (IC). Aluminate, carbonate, and hydroxide were measured using a titration method employing $\mathrm{BaCl}_{2}$ to precipitate carbonate allowing the determination of all three species. Aluminum, as well as other metallic elements, were measured using inductivelycoupled plasma-emission spectroscopy (ICP-ES). Mercury was determined using cold vapor atomic absorption. Gamma emitting fission products were measured using gamma spectroscopy. Actinides, noble metals and $\mathrm{Tc}^{99}$ were determined by a combination of inductively-coupled plasma mass spectrometry (ICP-MS) and alpha counting spectroscopy. $\mathrm{Sr}^{90}$ was determined from beta liquid scintillation counting.

\section{Dissolution tests}

Tests were conducted on the two annulus samples (HTF-087 and CPHTF-088) to explore the ability of tank farm compatible reagents to dissolve the material. For each annulus sample, duplicate tests with four reagents $(3 \mathrm{M} \mathrm{NaOH}, 0.01 \mathrm{M} \mathrm{NaOH}$, Process Water, and $4 \mathrm{wt} \%$ Oxalic Acid) were conducted at ambient temperature. In addition, dissolution tests at elevated temperature were conducted on the composite sample (CPHTF-088). The following general procedure was used in the tests.

A small portion of the moist sample $(0.5 \mathrm{~g})$ was placed in a $50 \mathrm{~mL}$ Oak Ridge centrifuge tube (polysulfone). The volume of the solids was noted after centrifugation for 10 minutes. A 5 $\mathrm{mL}$ aliquot of the reagent was transferred by pipette into the centrifuge tube being careful to minimize mixing. The centrifuge tubes containing the sample and reagent were allowed to sit undisturbed for 48 hours. Visual observations on the volume of solids remaining in the tubes were recorded periodically. After 48 hours the tubes were centrifuged for 10 minutes and decanted. A second $5 \mathrm{~mL}$ aliquot of the reagent was added to the centrifuge tube and remaining solids being careful to minimize mixing. Visual observations on the volume of solids remaining in the tubes were recorded periodically over 48 hours. At the end of the final 48 hour contact, each of the centrifuged tubes was vigorously shaken for several minutes periodically over the course of 2 hours to determine whether mixing would increase the dissolution of the sample. At the completion of the second contact with the reagent the 
tubes were centrifuged for 10 minutes, the liquid decanted from the solids, and the centrifuge tube with residual solids reweighed.

The elevated temperature tests were conducted by preheating the reagents in a $60^{\circ} \mathrm{C}$ oven prior to adding the reagents to the centrifuge tubes containing the sample. After adding the hot reagent, the centrifuge tubes containing the sample and reagent were placed into the 60 ${ }^{\circ} \mathrm{C}$ oven for the duration of the experiment. The door to the oven was opened periodically to visually assess the degree of dissolution of the sample.

\section{Characterization Results}

The characterization of the Tank $16 \mathrm{H}$ annulus and tank interior samples was hampered by the high dose rate and the nature of the samples. The high dose rate necessitated large dilutions of analytical samples leading to potentially large measurement errors as the analyte of interest approaches detection limits. Difficulties with obtaining representative aliquots of a non-homogenous solids sample also complicated the analysis. For the tank interior sample, difficulties with obtaining representative aliquots of a non-homogenous solids sample combined with the small amount of sample lead to increased potential for measurement error. The small amount of sample necessitated small aliquots for the acid digestion.

In an effort to reduce the error associated with large dilutions, samples of the acid digested annulus samples were contacted with a cesium removal resin (AMP-1) in the hope that a more concentrated sample could be analyzed. However, in both the composite sample (CPHTF-088) and HTF-087, the analytical data indicate the sample was corrupted by the method. The concentrations of the major elements of the samples $\mathrm{Na}, \mathrm{Al}, \mathrm{Fe}, \mathrm{Ca}, \mathrm{Hg}, \mathrm{Mg}$, $\mathrm{Mn}, \mathrm{K}, \mathrm{Cu}$ ) contacted with the cesium removal resin do not agree with the samples that were only diluted and showed large uncertainties. The ratios of the major elements concentrations also do not agree between the two sets of samples. In light of the obvious sample corruption the analytical data from the samples contacted with the cesium removal resin were discarded.

The results of the analysis of the Tank 16H samples (dilution only) are shown in Table 1 . With the exception of the most concentrated elements, the results of the analysis of the Tank $16 \mathrm{H}$ samples show large uncertainties as indicated by the percent relative standard deviation in parentheses.

The solids from the tank interior sample (HTF-086) are composed of predominantly iron containing compounds. The iron in the tank interior may be in the form of iron oxalate as a result of the extensive spray washing with oxalic acid during the tank cleaning demonstration. ${ }^{4}$ Anion analysis of the residual material at the end of the tank cleaning demonstration indicated that oxalate was the predominant anion. However, the presence of large amounts of oxalate in HTF-086 could not be confirmed due to insufficient sample. Sodium is the next most abundant element with small amounts of $\mathrm{Al}, \mathrm{Ca}, \mathrm{Mn}$, and $\mathrm{Ni}$.

The low dose rate of the tank interior sample was corroborated by the low concentrations of $\mathrm{Cs}^{137}$ and $\mathrm{Sr}^{90}$ detected. The total alpha was less than the detection limits. The only isotopes 
detected by ICP-MS were $\mathrm{U}^{238}$ and $\mathrm{Tc}^{99}$. An upper limit for $\mathrm{Pu}^{239}$ in the sample of $<0.3$ $\mu \mathrm{Ci} / \mathrm{g}$ can be calculated based on an ICP-MS detection limit of $1 \mathrm{ppb}$.

Sodium is the predominant element of the Tank $16 \mathrm{H}$ annulus sample HTF-087 with small amounts of $\mathrm{K}, \mathrm{Fe}$, and $\mathrm{Hg}$. The analytical results indicate the sample is composed of sodium salts with very little contamination of sand or sludge materials. The low degree of sludge/sand contamination found in the analysis agrees with the visual observations of the sample. The radionuclide concentrations are higher in HTF-087 as compared to the tank interior sample. The $\mathrm{Cs}^{137}$ and $\mathrm{Tc}^{99}$ are approximately $2 \mathrm{X}$ higher and the $\mathrm{Sr}^{90}$ approximately an order of magnitude higher than in the tank interior sample. The total alpha and the $\mathrm{Pu}^{239}$ are bounded by the lower detection limits for the analysis.

As observed in the visual analysis, the composite annulus sample (CPHTF-088) is also comprised mostly of sodium salts as evidenced by the high sodium concentration. However, the composite sample has much more sludge/sand material (Al, Fe, Ca) than HTF-087.

The $\mathrm{Cs}^{137}$ concentration agrees with the high dose rate measured on the samples combined to form the composite sample. The $\mathrm{Cs}^{137}$ concentration in the composite sample is $25 \mathrm{X}$ higher than HTF-087 and 50X higher than the tank interior sample. Unlike the tank interior sample and HTF-087, the alpha concentration of the composite was measurable. However, due to $100 \mathrm{X}$ dilution required to remove the sample from the Shielded Cells, no isotopes were measurable in the ICP-MS. Using a detection limit of $1 \mathrm{ppb}$, the upper limits for the concentrations of $\mathrm{Tc}^{99}, \mathrm{U}^{238}$, and $\mathrm{Pu}^{239}$ are shown in Table 1 .

The composite sample was also analyzed for the composition of inhibited water $(0.01 \mathrm{M}$ $\mathrm{NaOH}$ ) soluble components. Due to the low solubility of the composite sample very little data was obtained. However, the high sensitivity of the ICP-MS allowed determination of the soluble component of the $\mathrm{U}^{238}$ and $\mathrm{Tc}^{99}$ in the sample (Table 2). The concentrations of the soluble $\mathrm{U}^{238}$ and $\mathrm{Tc}^{99}$ in the sample agree with the upper limits measured in the aqua-regia dissolutions of the total solids. The measurement of the soluble $\mathrm{U}^{238}$ and $\mathrm{Tc}^{99}$ concentrations (Table 2) and the upper concentration limits in the total solids (Table 1) serve to bound the concentrations present in the total solids of the composite sample. Sodium and $\mathrm{Sr}^{90}$ were also measured in the soluble solids analysis. The data indicates that even large volumes of inhibited water would not dissolve $\sim 30 \%$ of the sodium.

The large uncertainties coupled with the number of important species below detection limits indicate the need for reanalysis of the Tank $16 \mathrm{H}$ samples. The reanalysis can be conducted on the current samples or preferably after completing further waste removal. Some possible remedies for the difficulties encountered in the initial analysis include:

- Use smaller dilution factors and prepare special radiation worker permits if required to remove the samples from the Shielded Cells.

- Use larger sample aliquots in the acid digestion to decrease difficulties with obtaining a representative aliquot from a non-homogenous solids sample. 
- Refine a cesium removal method for use in the Shielded Cells.

- Prepare a slurry of a large portion of the solids sample prior to obtaining aliquots for the acid digestion to decrease difficulties with obtaining a representative aliquot from a non-homogenous solids sample.

\section{Results of the Dissolution Tests}

The results of the dissolution tests with the annulus samples from Tank 16H provide qualitative evidence on the viability of the tested reagents as waste removal aids. The results are based on visual examination of the percentage of the sample in the centrifuge tube that dissolved. Using visual examination could potentially be misleading. For example, if a large percentage of the solids dissolve but the remaining solids become fluffy, the mistaken conclusion might be drawn that very little sample dissolved. Conversely, if very little sample dissolved but the remaining solids compact, it may appear that a large percentage of the sample dissolved.

The photographs in Figure 3 show the centrifuge tubes after the completion of the dissolution tests. The upper half of the figure shows the composite annulus sample (CPHTF-088) after two contacts at $60^{\circ} \mathrm{C}$. The photographs of the other annulus sample (HTF-087) after two contacts at ambient temperature are shown in the lower half of the figure. All of the centrifuge tubes in each test contained approximately the same volume of solids initially. The initial volume of solids is best represented in the photographs of CPHTF- 088 after two 48 hour contacts at $60^{\circ} \mathrm{C}$ with $0.01 \mathrm{M} \mathrm{NaOH}$. Each test was run in duplicate producing the two photographs for each set of conditions.

In general, none of the reagents appeared to be effective in dissolving the composite sample (CPHTF-088) even after two contacts at $60^{\circ} \mathrm{C}$. The $4 \mathrm{wt} \%$ oxalic acid at $60^{\circ} \mathrm{C}$ appeared to be the most effective reagent for the composite sample. In contrast to the composite sample, all of the reagents dissolved a large percentage of the other annulus samples (HTF-087) solids after two contacts at ambient temperature. The $4 \mathrm{wt} \%$ oxalic acid dissolved essentially all of the HTF-087 sample.

\section{Quality Assurance}

Laboratory notebook WSRC-NB-96-667 contains data from the characterization of samples from Tanks $16 \mathrm{H}$ and the dissolution tests. 


\section{References}

1. M. S. Hay, "Characterization Plan and Dissolution Tests for Tank 16H Samples", WSRC-RP-98-00032, February 9, 1998.

2. M. S. Hay, "Task and QA Plan for the Characterization and Dissolution Tests for Tank 16H Samples", WSRC-RP-98-00115, March 16, 1998.

3. Technical Task Request HLE-TTR-98014.

4. W. L. West, "Tank 16 Demonstration Water Wash and Chemical Cleaning Results", DPSP-80-17-23, December 16, 1980. 


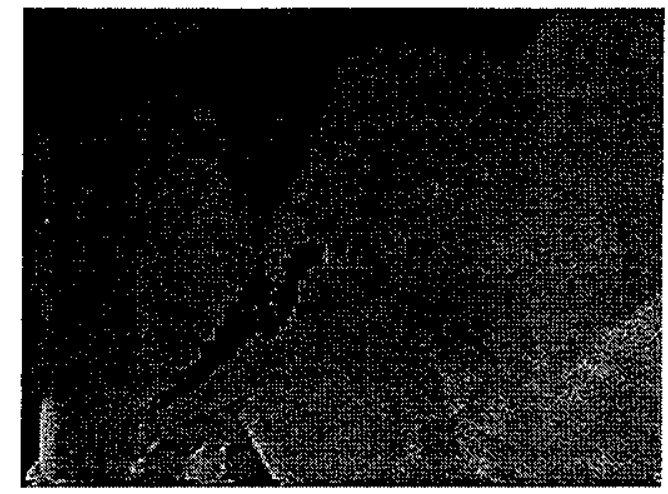

Tank 16 Tank Interior Sample HTF-086

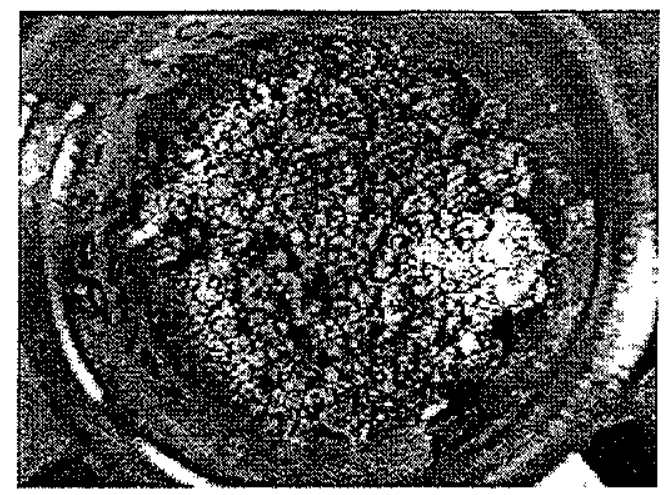

Tank 16 Annulus Sample HTF-088

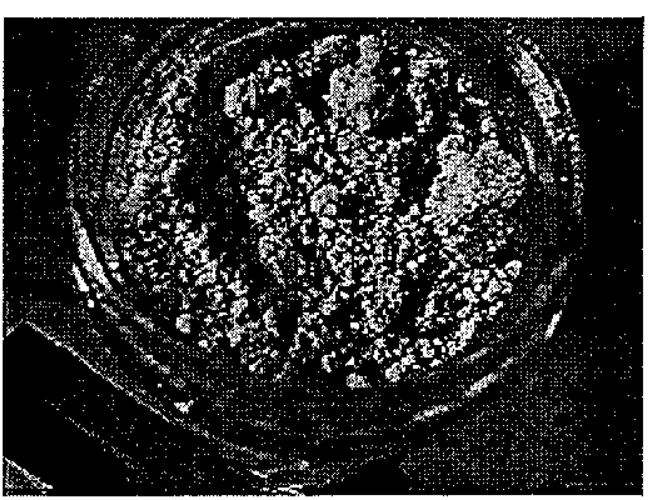

Tank 16 Annulus Sample HTF-090

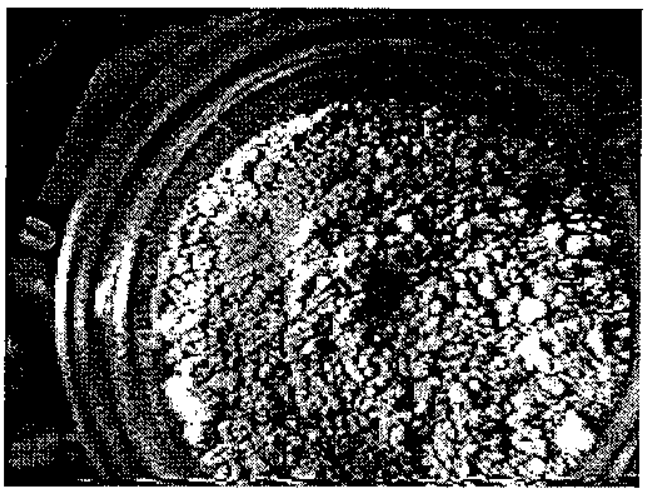

Tank 16 Annulus Sample HTF-087

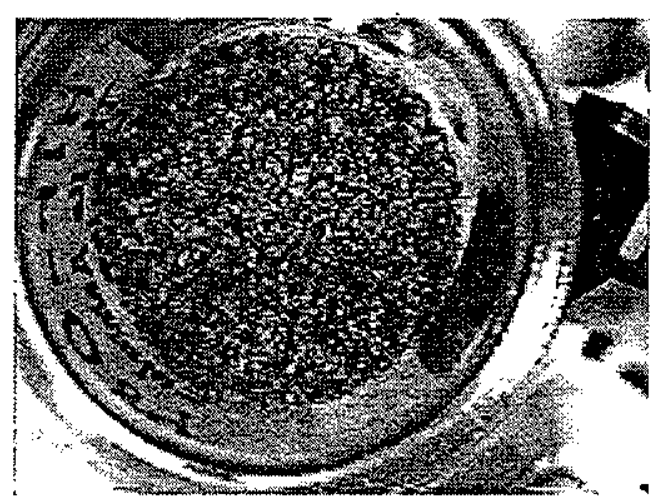

Tank 16 Annulus Sample HTF-089

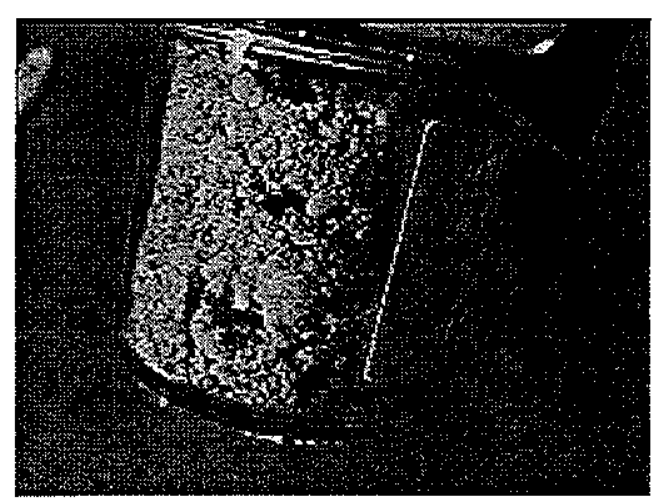

Tank 16 Annulus Sample HTF-091

Figure 1. Photos of Tank 16 Sample Jars 


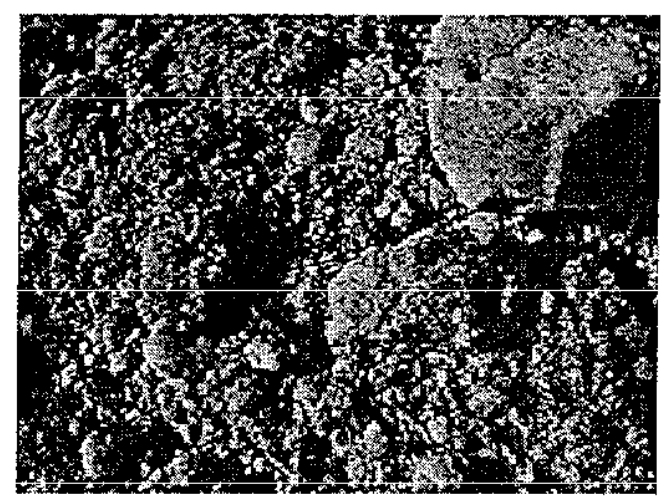

Tank 16 Annulus Sample HTF-087

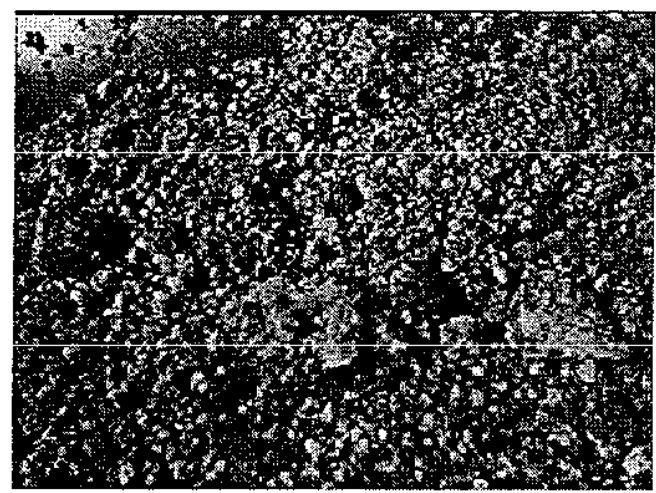

Tank 16 Annulus Sample HTF-089

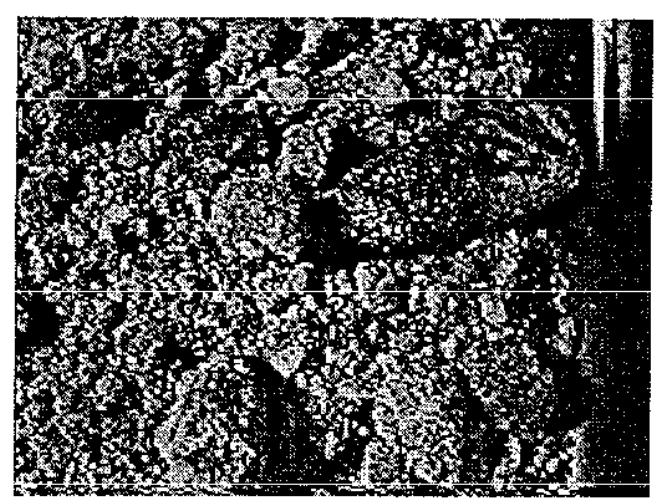

Tank 16 Annulus Sample HTF-088

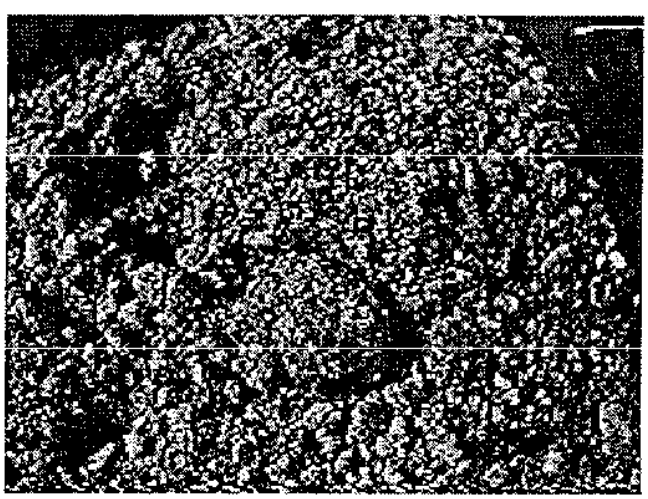

Tank 16 Annulus Sample HTF-090

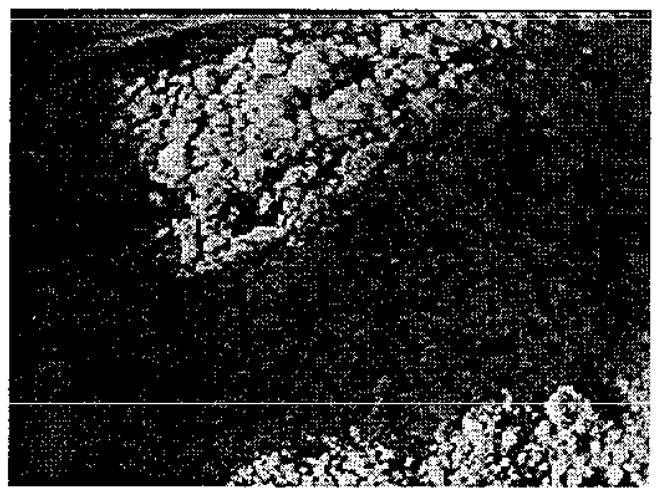

Tank 16 Annulus Sample HTF-091

Figure 2. Photos of Solids in Tank 16 Samples 


\section{CPHTF-088 Dissolution Tests}

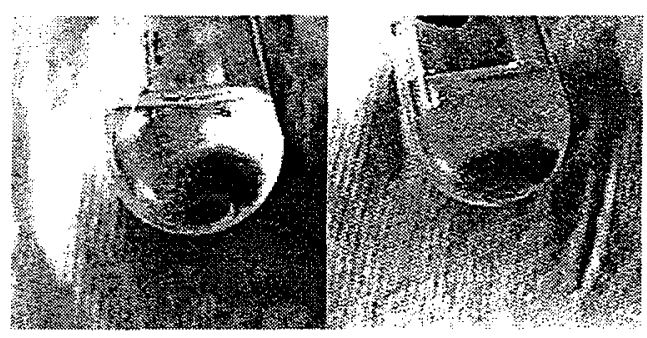

CPHTF-088 after two 48 hour contacts at $60^{\circ} \mathrm{C}$ with $3 \mathrm{M} \mathrm{NaOH}$.

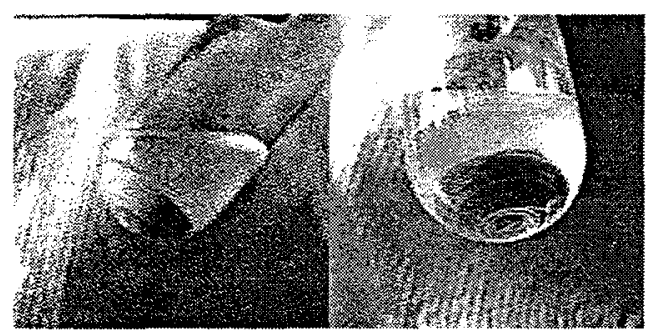

CPHTF-088 after two 48 hour contacts at $60^{\circ} \mathrm{C}$ with Process Water.

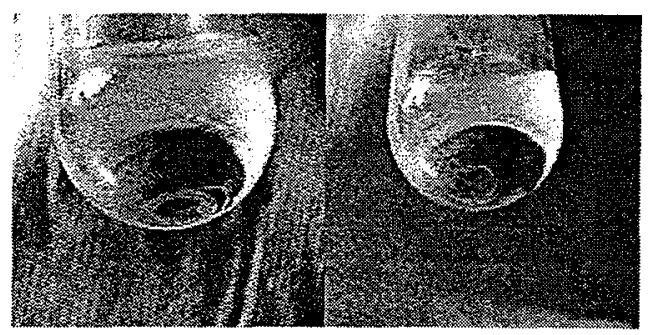

CPHTF-088 after two 48 hour contacts at $60^{\circ} \mathrm{C}$ with $0.01 \mathrm{M} \mathrm{NaOH}$.

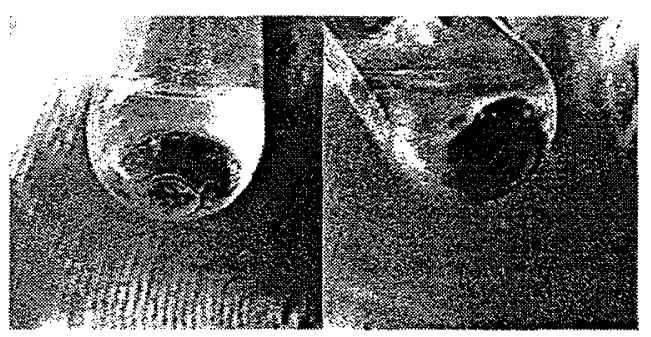

CPHTF-088 after two 48 hour contacts at $60^{\circ} \mathrm{C}$ with 4 wt $\%$ Oxalic Acid.

\section{HTF-087 Dissolution Tests}

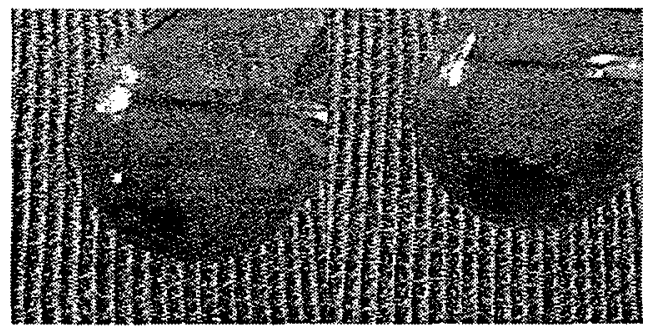

HTF-087 after two 48 hour contacts at ambient temperature with $3 \mathrm{M} \mathrm{NaOH}$.

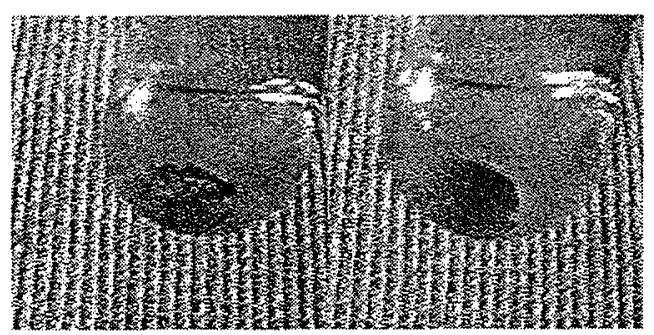

HTF-087 after two 48 hour contacts at ambient temperature with Process Water.

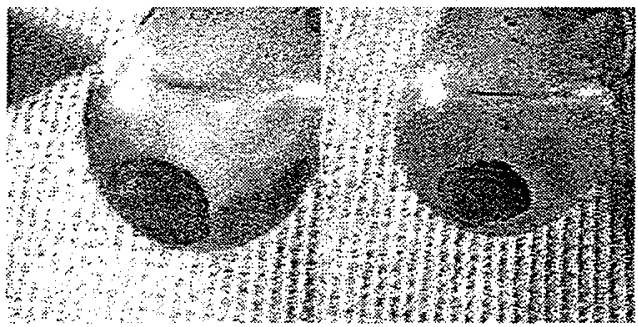

HTF-087 after two 48 hour contacts at ambient temperature with $0.01 \mathrm{M} \mathrm{NaOH}$.

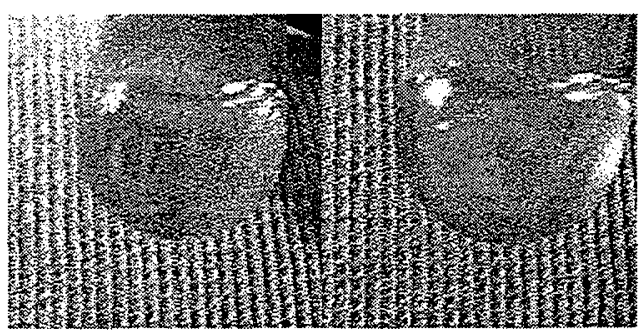

HTF-087 after two 48 hour contacts at ambient temperature with $4 \mathrm{wt} \%$ Oxalic Acid. 
Table 1. Results of the Total Dried Solids Analysis of Tank 16H Samples

\begin{tabular}{|c|c|c|c|c|}
\hline & Units & $\begin{array}{c}\text { Tank 16H Interior Sample } \\
\text { HTF-086 }\end{array}$ & $\begin{array}{c}\text { Tank 16H Annulus Sample } \\
\text { HTF-087 }\end{array}$ & $\begin{array}{c}\text { Tank } 16 \text { Annulus Sample } \\
\text { Composite } \\
\text { CPHTF-088 } \\
\end{array}$ \\
\hline $\mathrm{Cs}^{137}$ & $\mu \mathrm{Ci} / \mathrm{g}$ & $5.3 E+01(21)$ & $9.8 \mathrm{E}+01(10)$ & $2.5 E+03(13)$ \\
\hline $\mathrm{Sr}^{90}$ & $\mu \mathrm{Ci} / \mathrm{g}$ & $3.1 \mathrm{E}+01(26)^{\circ}$ & $3.2 \mathrm{E}+02(4)$ & $4.7 \mathrm{E}+02(19)$ \\
\hline $\mathrm{Tc}^{99}$ & $\mu \mathrm{Ci} / \mathrm{g}$ & $6.2 \mathrm{E}-02(6)$ & $1.3 \mathrm{E}-01(27)$ & $<4.0 \mathrm{E}-01$ \\
\hline Alpha ${ }^{\text {total }}$ & $\mu \mathrm{Ci} / \mathrm{g}$ & $<1.9 \mathrm{E}+00$ & $<4.1 \mathrm{E}+00$ & $3.4 \mathrm{E}+01(82)$ \\
\hline $\mathrm{Pu}^{239}$ & $\mu \mathrm{Ci} / \mathrm{g}$ & $<3.0 \mathrm{E}-01$ & $<7.5 \mathrm{E}-01$ & $<1.5 \mathrm{E}+00$ \\
\hline $\mathrm{U}^{238}$ & wt $\%$ & $1.6 \mathrm{E}-02(17)$ & $2.6 \mathrm{E}-03(38)$ & $<3.0 \mathrm{E}-03$ \\
\hline $\mathrm{Al}$ & wt $\%$ & $1.7 \mathrm{E}-01(12)$ & $<3.7 \mathrm{E}-02$ & $7.9 E+00(10)$ \\
\hline B & wt $\%$ & $<6.7 \mathrm{E}-03$ & $<1.3 \mathrm{E}-02$ & $<2.8 \mathrm{E}-02$ \\
\hline $\mathrm{Ba}$ & wt $\%$ & $4.9 \mathrm{E}-03(20)$ & $<3.7 \mathrm{E}-03$ & $<7.6 \mathrm{E}-03$ \\
\hline $\mathrm{Ca}$ & wt $\%$ & $1.2 \mathrm{E}-01(31)$ & $<8.6 \mathrm{E}-03$ & $1.2 \mathrm{E}+00(36)$ \\
\hline $\mathrm{Cd}$ & wt $\%$ & $7.3 \mathrm{E}-03(20)$ & $<2.4 \mathrm{E}-03$ & $<5.1 \mathrm{E}-03$ \\
\hline Co & wt $\%$ & $<8.5 \mathrm{E}-03$ & $<1.7 \mathrm{E}-02$ & $<3.5 \mathrm{E}-02$ \\
\hline $\mathrm{Cr}$ & wt $\%$ & $3.4 \mathrm{E}-02(55)$ & $<7.3 \mathrm{E}-03$ & $2.8 \mathrm{E}-02(25)$ \\
\hline $\mathrm{Cu}$ & wt \% & $3.1 \mathrm{E}-03(72)$ & $<2.4 \mathrm{E}-03$ & $1.4 \mathrm{E}-01(8)$ \\
\hline $\mathrm{Fe}$ & wt \% & $3.5 E+01(16)$ & $2.9 \mathrm{E}-01(11)$ & $1.3 \mathrm{E}+00(43)$ \\
\hline $\mathrm{Hg}$ & $w t \%$ & $<6.1 \mathrm{E}-03$ & $8.5 \mathrm{E}-01(12)$ & $5.2 \mathrm{E}-01(13)$ \\
\hline $\mathrm{K}$ & $w t \%$ & $<1.2 \mathrm{E}-01$ & $1.4 \mathrm{E}+00(3)$ & $<4.9 \mathrm{E}-01$ \\
\hline $\mathrm{Mg}$ & wt \% & $3.5 \mathrm{E}-02(10)$ & $<3.7 \mathrm{E}-03$ & $7.4 \mathrm{E}-02(49)$ \\
\hline $\mathrm{Mn}$ & wt \% & $1.7 \mathrm{E}-01(15)$ & $<3.7 \mathrm{E}-03$ & $8.9 \mathrm{E}-03(21)$ \\
\hline $\mathrm{Na}$ & wt \% & $6.5 E+00(47)$ & $2.9 \mathrm{E}+01(2)$ & $1.6 \mathrm{E}+01(13)$ \\
\hline $\mathrm{Ni}$ & $w t \%$ & $1.6 \mathrm{E}-01(83)$ & $<1.2 \mathrm{E}-02$ & $<2.5 \mathrm{E}-02$ \\
\hline $\mathbf{P}$ & wt \% & $6.1 \mathrm{E}-02(30)$ & $<3.3 \mathrm{E}-02$ & $<6.8 \mathrm{E}-02$ \\
\hline $\mathrm{Pb}$ & wt $\%$ & $<1.6 \mathrm{E}-02$ & $<3.3 \mathrm{E}-02$ & $<6.8 \mathrm{E}-02$ \\
\hline Sn & wt \% & $<7.3 \mathrm{E}-03$ & $<1.5 \mathrm{E}-02$ & $<3.0 \mathrm{E}-02$ \\
\hline $\mathrm{Sr}$ & $w t \%$ & $<1.2 \mathrm{E}-03$ & $<2.4 \mathrm{E}-03$ & $<5.1 \mathrm{E}-03$ \\
\hline $\mathrm{Ti}$ & $w t \%$ & $<1.8 \mathrm{E}-03$ & $<3.7 \mathrm{E}-03$ & $<7.6 \mathrm{E}-03$ \\
\hline V & wt \% & $<1.8 \mathrm{E}-03$ & $<3.7 \mathrm{E}-03$ & $<7.6 \mathrm{E}-03$ \\
\hline $\mathrm{Zn}$ & wt \% & $5.5 \mathrm{E}-02(11)$ & $<3.7 \mathrm{E}-03$ & $2.4 \mathrm{E}-02(24)$ \\
\hline
\end{tabular}

Quantities in parentheses indicate the percent relative standard deviation (RSD) of two or more replicate samples. The RSD is the standard deviation expressed as a percentage of the mean and provides a measure of the analytical uncertainty. The RSD in the table does not include the sampling uncertainty. 
Table 2. Analytical Results of the Soluble Solids Analysis of the Tank 16H Composite Sample (CPHTF-088).

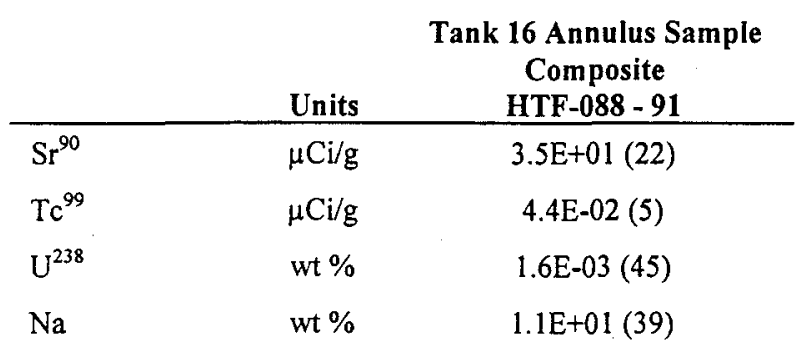

Note: The soluble solids were determined by contacting $0.1 \mathrm{~g}$ of the sample with $100 \mathrm{~mL}$ of inhibited water $(0.01 \mathrm{M} \mathrm{NaOH})$.

Quantities in parentheses indicate the percent relative standard deviation (RSD) of two or more replicate samples. The RSD is the standard deviation expressed as a percentage of the mean and provides a measure of the analytical uncertainty. The RSD in the table does not include the sampling uncertainty. 